Jurnal Keperawatan Silampari

Volume 4, Nomor 1, Desember 2020

e-ISSN: 2581-1975

p-ISSN: 2597-7482

DOI: https://doi.org/10.31539/jks.v4i1.1601

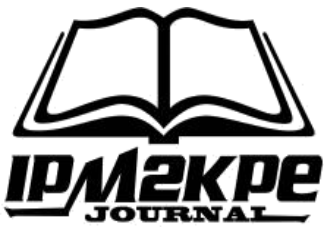

\title{
STUDI FENOMENOLOGI: PENGALAMAN REMAJA DALAM MENGGUNAKAN NARKOBA
}

\author{
Ketut Suryani ${ }^{1}$, Bangun Dwi Hardika ${ }^{2}$, Maria Tarisia Rini ${ }^{3}$ \\ Universitas Katolik Musi Charitas ${ }^{1,2,3}$ \\ suryani@ukmc.ac.id ${ }^{1}$
}

\begin{abstract}
ABSTRAK
Penelitian ini bertujuan untuk menggali dan mengeksplorasi secara mendalam mengenai pengalaman remaja dalam menggunakan narkoba. Metode penelitian ini menggunakan metode penelitian kualitatif dengan pendekatan fenomenologi. Hasil dari penelitian didapatkan dua belas tema, yaitu : 1) Usia remaja menggunakan narkoba, 2) Penyebab awal remaja menggunakan narkoba, 3) Frekuensi pemakaian narkoba pada remaja, 4) Jenis narkoba yang digunakan oleh remaja, 5) Cara remaja mendapatkan narkoba, 6) Upaya remaja untuk berhenti menggunakan narkoba, 7) Perasaan remaja setelah menggunakan narkoba, 8) Harapan remaja yang menggunakan narkoba, 9) Dampak remaja yang menggunakan narkoba, 10) Efek remaja jika tidak menggunakan narkoba, 11) Persepsi remaja mengenai narkoba, 12) Respon remaja saat menggunakan narkoba. Simpulan, dampak dalam menggunakan narkoba pada remaja didapatkan ada beberapa remaja yang mengatakan badanya kurus, kehilangan orang tua dan sampai berhenti sekolah.
\end{abstract}

Kata Kunci : Colaizzi, Fenomenologi, Narkoba, Remaja

\section{ABSTRACT}

This study aims to explore and explore in-depth the experiences of adolescents in using drugs. This research method uses qualitative research methods with a phenomenological approach. The results of the study obtained twelve themes, namely: 1) The age of adolescents using drugs, 2) The initial causes of adolescents using drugs, 3) The frequency of drug use in adolescents, 4) The types of drugs used by adolescents, 5) How adolescents get drugs, 6) Adolescent's efforts to stop using drugs, 7) Adolescent's feelings after using drugs, 8) The expectations of adolescents who use drugs, 9) The impact of adolescents using drugs, 10) The effects of adolescents if they do not use drugs, 11) Youth perceptions of drugs, 12) Adolescent response when using drugs. In conclusion, the impact of using drugs on adolescents was that some adolescents said they were thin, lost their parents, and quit school.

Keywords: Colaizzi, Phenomenology, Drugs, Teenagers

\section{PENDAHULUAN}

Penelitian yang dilakukan Amanda et al., (2017) menunjukkan bahwa masih banyak remaja yang mengabaikan nilai-nilai kaidah norma serta hukum dan mencoba mengikuti keiginan sendiri dengan mencoba hal-hal baru salah- satunya menggunakan narkoba.

Salah satunya perubahan yang negatif yang menyebabkan remaja melakukakan ha-hal baru yang diluar norma yang berasal dari pergaulan dengan teman dan lingungan. Salah satu adalah mencoba untuk mengguna narkoba. Muhsinin et al., (2017) mengatakan bahwa teman 
sebaya mempunyai kecenderungan dalam penggunaan NAPZA pada remaja dengan $p$ value 0.00. Sejalan dengan hasil penelitian yang dilakukan Fitriani et al., (2017) menunjukkan dari delapan variabel, hanya enam variabel yang memiliki hubungan dengan risiko penyalahgunaan narkoba pada remaja/pelajar, variabel tersebut antara lain faktor narkoba, ketersediaan dan kemudahan mendapatkan narkoba faktor individu, jenis kelamin faktor lingkungan, keluarga dan teman (pergaulan).

Penggunaan narkoba pada kalangan remaja dikarenakan kekurangan pengetahuan akan dampak penggunaan narkoba. Penelitian yang dilakukan Herman et al., (2019) menunjukkan pengetahuan informan belum cukup baik karena kurang paham terhadap informasi yang diterima, hal ini ditunjukkan dimana informan bersikap acuh dan memiliki kecenderungan untuk tetap menggunakan narkoba karena sudah mengalami kecanduan.

Menurut World Drugs Reports 2018 yang diterbitkan oleh United Nations Office on Drugs and Crime (UNODC), menyebutkan sebanyak 275 juta penduduk di dunia atau 5,6\% dari penduduk dunia ( 15-64 tahun) pernah mengkonsumsi narkoba. Menurut BNN tahun 2017 sebanyak 3.376.115 orang di Indonesia pada rentang usia 10-59 tahun, di kalangan remaja menggunakan narkoba sebesar 3,21\% dari 100.000/penduduk (BNN, 2019). Di Sumatera Selatan remaja yang menggunakan narkoba sebesar 16.000 dari 100.000/ penduduk (Badan Narkotika Nasional RI, 2017).

Narkoba atau obat-obatan terlarang lainnya sangat membahayakan dan merugikan remaja sebagai asset masa depan bangsa. Penyalahgunaan narkoba pada remaja di Indonesia sudah mencapai tahap yang sangat mengkhawatirkan. Tidak hanya pada kalangan remaja di perkotaan bahkan sudah menjalar ke kalangan anak-anak yang berada di pedesaan (Supratman, 2018). Semakin ketergantungan terhadap narkoba maka akan semakin besar dampak yang ditimbulkan terutama di tingkat keluarga dan lingkungan sekitar.

Dampak akibat penyalahgunaan narkoba dapat beresiko terkena berbagai penyakit diantaranya yaitu beresiko menularkan HIV melalui jarum suntik yang tidak steril secara berganti-gantian sakit syaraf/sendi, hepatitis $\mathrm{C}$ dan kejiwaan/depresi, serta penyakit paru-paru. Penyalahgunaan narkoba berdampak langsung bagi tubuh maupun mental. Tiap zat memberikan efek yang berbeda terhadap tubuh yang dapat menyerang organ tubuh dan dapat terinfeksi penyakit menular (Pusat Data dan Informasi, 2017).

Penelitian yang dilakukan Madyarartri et al., (2017) menunjukkan bahwa ada beberapa tema penting mengenai narkoba. Tema-tema tersebut antara lain sebagai berikut : kondisi keluarga, sebagai tempat pelarian, solidaritas antar kelompok dan pengaruh teman sekolah dan gambaran seorang figur ayah.

Penelitian sebelumnya sudah pernah dilakukan terkait penggunaan pada remaja, namun pada penelitian ini berfkus pada pemahaman dan mengekplorasi pengalaman remaja yang terkait tentang kondsisi lingkungan, karateristik remaja dalam menggunakan narkoba.

\section{METODE PENELITIAN}

Penelitian ini menggunakan desain penelitian kualitatif dengan pendekatan fenomenologi. Penelitian dilaksanakan pada bulan Agustus sampai September 2020. Partisipan dalam penelitian ini berjumlah 6 remaja yang menggunakan narkoba. Partisipan diambil dengan menggunakan teknik purposive sampling dan snowball. Metode analisa yang digunakan menggunakan analisa coalizzi. Teknik pengumpulan data yang digunakan dengan wawancara mendalam dengan pertanyaan terbuka. 


\section{HASIL PENELITIAN}

\section{Tema 1: Usia Remaja Menggunakan Narkoba}

Usia remaja menggunakan narkoba termasuk dalam kategori remaja awal dan remaja tengah. Berikut peryataan partispan sebagai berikut:

“..kan kiro-kiro umur ak 10 tahun lah”( P3)

"Sekitar empat belas tahun lah" (P5).

"sekitar empat belas lima belas tahun lah" (P6)

"pertamo buk, saya ini kan dari umur 16 tahun aibon.."(P1)

"makek ini ni dari umur 17 tahun mbak.."(P2)

“dari tujuh belas sampe duo satu” (P4)

\section{Tema 2 : Penyebab Awal Remaja Menggunakan Narkoba}

Penyebab awal remaja menggunakan narkoba teridentifikasi dari tiga kategori yaitu teman, keluarga dan diri sendiri. Berikut pernyataan partispan yang termasuk kedalam penyebab remaja menggunakan nakoba :

“emm, jingok-jingok uong, kepengen.." (P1)

"kemaren tu nyabu tu uji aku dak lemak kemaren itu kan kuraso kan tapi nyelek-nyelek kawan bae kan (sambil melihat ke samping kiri)”(P2)

"..nyabu disuruh kawan ciciplah lemak uji dio ngomongkan (sambil melihat ke sebelah kiri) iyo jeralah aku cicipkan duo asap apo tigo asap tigo asap..."(P2)

“...dikasih kawan, aku kan keluar maen pas sekolah SD itu kan, naek pohon rambutan.., dikasihnyo.."(P3)

"diajak kawan asal mulanya"(P4)

"melihat kawan makek itu jadi pengen" (P5)

"iyo karno yang lain pada minum obat tersebut jadi saya menggunakan juga" (P6)

“...ayah aku galak kasa i aku, ayah aku jugo samo mamak aku ni la cerai ..” (P1)

"penyebab lain yoh sering dimarah-marah oleh wong tuo nah buk"(P4)

"Kecewa enggak ngijini orang tua saya untuk sekolah negri (P6)

"frustasi buk, ditinggal cewek"(P4)

"coba-coba saja" (P5)

"Karena saya telat mendaftar SMA apa namanya waktu itu saya ngetes ke negri tidak masuk jadinya saya frustasi” (P6)

"Yah pertamo memang dari hasrat diri yah" (P6)

\section{Tema 3 : Frekuensi Pemakaian Narkoba pada Remaja}

Frekuensi pemakaian narkoba sangat beragam, mulai dari yang seminggu sekali hingga seminggu 3 kali. Ada juga yang mengungkapkan bahwa memakai narkoba setiap hari. Berikut ini merupakan pernyataan partisipan yang termasuk kedalam frekuensi permakaian narkoba :

"kadangan 2 hari sekali, kadangan kalo lagi ado bae, sehari 1 kali”(P1)

"dak tentu, kapan ado duet bae mbak,kadang seminggu sekali.." (P2)

"duo kaleng tu seminggu.." (P3)

"seminggu tigo kali.." (P4)

"paling lama seminggu itu tiga kali makek (P5)

“Setiap minggu itu kan setiap hari tiap kalo tidak punya uang tidak pakek obat”(P5) 


\section{Tema 4: Jenis Narkoba yang Digunakan oleh Remaja}

Jenis narkoba yang digunakan oleh remaja mulai dari golongan 1, 2 dan 3. Cara ini teridentifikasi menjadi 3 kategori. Golongan I kategori teridentifikasi berdasarkan pernyataan partisipan. Partisipan 3 mengatakan bahwa ketergantungan memakai lem aibon sehingga ingin membelinya terus. Partisipan mengungkapkan menggunakan narkoba jenis sabu. Pernyataan tersebut diungkapkan oleh partisipan 2 dan 4. Partisipan 5 mengatakan bahwa memakai narkoba jenis ganja dan sabu. Sedangkan partisipan 6 mengatakan bahwa memakai narkoba jenis sabu-sabu dan awalnya mememakai lem aibon.

"iyo aibon" (P1)

“...disitu aku nyabu, cicipkan duo asap apo tigo asap tigo asap...” (P2)

“karena ngibon.., maseh dak galak lepas, nak beli teros" (P3)

“sabu” (P4)

"oh yang dua ribu lima belas itu makek ganja”(P5)

" dua ribu tujuh belas baru menggunakan sabu (P5)

"gunain sabu-sabu juga (P6)

“ pertama kali... iya karena dulunya saya juga pengguna aibon mbak (P6)

\section{Tema 5 : Cara Remaja Mendapatkan Narkoba}

Cara remaja mendapatkan narkoba mulai teman hingga kondisi lingkungan. Berikut ini merupakan pernyataan partisipan:

“dak pernah beli, karno kawan dio banyak, dari kawan gale itu buk..”(P1)

"ceka samo kawan"(P4)

"beli dari teman, uang jajan sendiri”(P5)

"paling majaki temen”(P5)

"ya gak lah, iya beli sendiri”"(P6)

“...kadang tu makso makso ayuk mintak duet”(P3)

"ngambil duit wong tuo"(P4)

"beli yo banyak wong jualan begeteng setiap lorong ado (sambil melihat ke sebelah kiri dan tertawa)"(P2)

"kalo ado duet nak beli itu tula, sampe habis duet..."(P3)

"Ini apa namanya saya sampe menggadaikan hp tuk beli itu”(P6)

\section{Tema 6 : Upaya Remaja untuk Berhenti Menggunakan Narkoba}

Upaya remaja untuk berhenti menggunakan narkoba teridentifikasi menjadi dua kategori yaitu usaha keluarga dan usaha diri sendiri. Berikut ini merupakan kategori yang termasuk kedalam upaya remaja untuk berhenti menggunakan narkoba :

"pikiran saya kalu jangan lagi nak, gek dimodali ninek bewarong, diomongi nenek, gek kau bewarong, bini kau ku carikan katonyo"(P1)

“...wong tuo aku cepet-cepet bawak kesini kan dengan bapak ini untuk biar aku ini kan kuat berenti nian itu nah (sambil mengerakkan kaki)"(P2)

"dimasokinyo disinilah, rehap teros, la ado cak 10 kali, di ernaldi bahar 5, disini 5 kali pulo, selalu dimasoki"(P3)

“...keno marah, dikibet..”(P3)

"ketauan samo mama aku, langsung diobawa erba"(P4)

“...aku tu nak nyari bini,pengen nyari bini.."(P1)

"yo bekerjalah, yang biso ngelupoke sabu tuh hanya ado gawean kalo katek gawean itulah tadi mbak ujung-ujungnyo balek dari sini payah payah berobat ngulang lagi nyabu..."(P2) 
“...intinyo dari diri kito dulu menjauhi sudah men kito lah jauh dari sano insyaallah biso dak lagi...”(P2)

“itulah.., tahanke bae, tahanke nian, dirumah tula, biar dak ngisep lagi "(P3)

"beribadah"(P4)

"menjauh dengan yang pakai itu dak usah dikawani lagi”(P4)

\section{Tema 7 : Perasaan Remaja Setelah Menggunakan Narkoba}

Perasan remaja setelah menggunakan narkoba mengungkapkan hal yang sama yaitu perasaan menyesal dan lelah setelah menggunakan narkoba.

"saya menyesal makek-makek itu buk"(P1)

“...tapi rencano nak berenti nian aku jero dak lagi”(P2)

"sudahnyo nyesal, kareno banyak nian hukamnnyo, dilarang nian itu”(P3)

“iyo nyesel lah kito kawan-kawan sehat idak makek itu kan kito makek itu dak sehat”(P4)

"Ada penyesalan karena menggunakan barang terlarang "(P5)

"yang pasti punya penyesalan kalau disangkut paut dengan orang tua" (P6)

" punya mbak pokoknya cita-cita tapi sudah enggak bisa lagi mbak, nyesel aku” (P6)

\section{Tema 8 : Harapan Remaja yang Menggunakan Narkoba}

Harapan remaja yang menggunakan narkoba ingin mencari istri setelah pulang dari rehabilitasi, ingin pulang lalu bekerja, lebih menata masa depan dan bebas dari narkoba, ingin disemangati oleh orang tua untuk benar-benar berhenti dari narkoba, ingin sembuh total, tidak bergaul dengan orang yang mengonsumsi narkoba, ingin bekerja dan membuka usaha sendiri dan menikah, ingin membahagiakan orang tua, ingin sembuh dan mewujudkan cita-cita hingga keperguruan tinggi, ingin pulih, ingin sembuh dan berubah. Berikut ini merupakan pernyataan partisipan yang termasuk kedala kategori keinginan :

“...nah cuma dari sini, balek dari sini kagek nyari bini"(P1)

“...aku pengen nak begawe bae mbak pening dak katek kesudahannyo paling di situsitulah paling agek masuk rumah sakit lagi aku sudah tigo kali masuk rumah sakit (pandangan ke samping sebelah kiri sambil tertawa) "(P2)

"...yoh untuk ado masa depan lah kedepannyo madaki wong cak ini-cak inilah dak katik sudahnyo..."(P2)

“...semestinyo bebas dari narkoba dah cak itu bae aku..."(P2)

"idak tergiur lagi cak itu (sambil memperagakan dengan menggerakkan tangan kanan)"(P2)

"pengen balek.."(P3)

“...aku pengennyo uong tuo aku tu kasih aku semangat, akuni nak berenti nian”(P3)

"yoh harapan aku sih sembuh total”(P4)

"nikah,,, kalo ado jodohnyo"(P4)

"ya aku pengen bahagiakan orang tua."(P5)

"bisa menjaga pemulihan, maksudnya biso sembuh ”(P5)

"menjadi lebih baik mbak, sebenernyo pengen bisa mencapai cita-cita sekolah sampai tinggi "(P5)

"yah rasanya pengen sembuh aja mbak, pengen pulih, pengen berubah" (P6).

\section{Tema 9 : Dampak Remaja yang Menggunakan Narkoba}

Dampak remaja yang menggunakan narkoba tergambarkan dalam penelitian ini. Berbagai dampak dirasakan remaja yang menggunakan narkoba. Dampaknya antara lain sering kejang karena terlalu ingin menggunakan narkoba, tidak enak di badan. hidungnya 
terasa membesar, penglihatanya kabur, badan terasa lumpuh, jarang pulang, menghancurkan kipas dan barang-barang yang ada dirumah dan kadang seperti orang mati yang tidak bernapas, berhenti jadi kelas 1 SMA. Ketika kambuh sering mengamuk atau marah-marah dirumah, melempar piring dan gelas, kadang menyendiri dan ngurung kamar, penglihatanya buram. Ada juga yang menyatakan gara-gara ini ayah sudah tidak ada, saat kambuh bertempramen tinggi dan marah-marah, tidak bisa tidur selama tiga hari atau seminggu jika memakai narkoba terlalu berlebihan. Pernyataan partisipan yang termasuk kedalam kategori efek pada dampak remaja yang menggunakan narkoba adalah sebagai berikut :

“kadang galak kejang kareno sakau makeknyo”(P1)

"dak lemak di badan.."(P2)

"kareno edong tebesak, mengot-mengot penjingokan, banyak lumpuh badan, kalo tedok siang teros, kadang malem-malem nak keluyuran teros jarang balek kerumah" (P3)

"berenti jadi kelas 1 SMA..."(P3)

“liat tubuh cak ini kan, la banyak bekas-bekas kapak uong”(P3)

"galak ngancori kipas kalo dak dikasih, ngancori barang-barang dalem rumah itu, ancor galo.."(P3)

“yo la celako cak ini, galak cak uong mati itu, dak benapas..."(P3)

"kumatnyo ngamuk-ngamuk aku di rumah, melempar piringlah, melempar gelas"(P4)

"perasaan tuh sering menyendiri ini nah buk, ngurung di kamar perasaan dak galak

bergaul dengan wong”(P4)

"yah gara-gara itu kan bapak katek lagi”(P4)

"agak buram mato"(P4)

"saya aja kadang tempramen emosionelnya suka tinggi.marah-marah"(P5)

"palingan yah dampaknya kan emosional perilaku”(P5)

"cuman dampaknya enggak bisa tidur, saya waktu itu tidak bisa tidur selama tiga hari kak, kadang seminggu kalau kelebihan pakek itu”(P6)

\section{Tema 10 : Efek Remaja Jika Tidak Menggunakan Narkoba}

Efek remaja jika tidak menggunakan narkoba teridentifikasi dari dua kategori, yaitu gejala secara fisik dan gejala secara psikologis. Kategori yang termasuk kedalam efek remaja jika tidak menggunakan narkoba adalah sebagai berikut :

"rasonyo men dak ganja tu buk, badan ni lesu (sambil melihat ke bawah) "(P1)

"efeknyo tadi kalo kito dak nyabu lesu badan (sambil meletakkan tangan di kursi duduk, mencondongkan badan kedepan dan melihat ke arah kiri) mak itu nah, nak begawe lesu, penyungkan.."(P2)

“apo cak pegel-pegel galo badan, ngilu-ngilu cak itu”(P4)

"mencak menggigil-menggigil cak itu nah"(P4)

"badan aja lemas ya kalau sudah gak makek itu”(P5)

"gelisah rasonyo, dak enak..”(P3)

"pusing tujuh keliling itu nah pusing nian cak itu nah"(P4)

“Lesu lah rasanya, pusing juga kalau misal gak makek ini” (P6)

\section{Tema 11 : Persepsi Remaja Mengenai Narkoba}

Persepsi remaja mengenai narkoba bahwa menghisap narkoba itu badannya kurus dan luka. Mengkonsumsi narkoba itu tidak enak. Ada juga yang mengungkapkan bahwa narkoba itu enak dan rasanya ingin beli terus, menyatakan senang-senang supaya tidak suntuk, narkoba itu enak dan narkoba jenis tumbuhan dan zat kimia rasanya enak. Pernyataan partisian yang termasuk kedalam persepsi remaja mengenai narkoba adalah sebagai berikut : 
“...ngisep ngisep narkoba tu borok, kurus badan...” (P1)

“...kepala pusing, kato uong lemak.., padahal dak lemak”(P1)

“...yoh dak katek mbak ehh aku jugo kemaren tu nyabu tu uji aku dak lemak...”(P2)

"kepingin.., enakk.., itu katonyo lem sendal, nak bel teros tu kan aibon.., kecanduan.., kelemakan, nak beli teros.."(P3)

"iyo, untuk happy bae biar dak suntuk pikiran"( P4)

"kalo mau diomongi enak, enak tanaman alami, zat kimia”(P5)

\section{Tema 12: Respon Remaja saat Menggunakan Narkoba}

Respon remaja saat menggunakan narkoba menyatakan rasanya tidak enak, pusing seperti berputar, semangat setelah mengkonsumsi narkoba. Ada yang mengungkapkan senang dan berasa seperti mimpi, jantungnya berdebar debar dan tidak bisa tidur, rasanya seperti terbang dan nafsu ,makan bertambah, badan terasa ringan, tidak ada pikiran, santai, merasa tenang dan nyaman. Berikut ini merupakan pernyataan partisipan yang termasuk kedalam respon remaja saat menggunakan narkoba:

"rasanya dipalak buk, pening.., ado raso beputer.."(P1)

"yo cak itulah semangat bae kalo kito sudah nyabu"(P2)

"enakk..,kato uong tu ilusi,cak mimpi tu nah, seneng.., enakk"(P3)

"perasaan itu melayang mbak melayang berhalusinasi lah"(P4)

"iyo ngeplay,ngeplay katek wong dirumah itu mencak terbang-terbang apo tuh maksudnyo tuh mencak ngeplay menghayal mak itu nah”(P4)

"debar-debar jantung, dak tedok"(P4)

"ngeplay, yang tadi mood makan nambah"(P5)

"saat makek yah santai bawaan pikiran, tidak ada pikiran,tenang, nyaman, oh pikiran enteng”"(P6)

“iya ngeplay, badan enteng "(P6)

\section{PEMBAHASAN}

\section{Tema 1: Usia Remaja Menggunakan Narkoba}

Hasil penelitian ini menunjukkan penggunaan narkoba berada pada tahap remaja awal dan remaja tengah. Sesuai dengan hasil penelitian ini remaja mencoba hal-hal baru dengan menggunakan narkoba dengan berbagai jenis dan pada usia remaja seperti partispan 1,2,4,5 dan 6 mengatakan bahwa menggunakan narkoba pada usia 14, 16 dan juga 17 tahun. Didukung penelitian (Nur'artavia, 2017) pelajar yang menyalahgunakan NAPZA adalah lakilaki, sebagian besar berada pada usia remaja awal (54,5\%), dan sedang menempuh tingkat pendidikan SMA (52\%). Selain itu penelitian (Veronica et al., 2018) menunjukkan bahwa usia remaja 15-19 sebanyak 65.4\% yang menggunakan narkoba. Hasil penelitian ini juga didapatkan lima dari partisipan yang menggunakan narkoba memiliki usia remaja tengah.

\section{Tema 2 : Penyebab Awal Remaja Menggunakan Narkoba}

Remaja yang menjadi partisipan dalam penelitian ini menyatakan bahwa penyebabnya dapat berasal dari teman hingga keluarga. Penyebab awal remaja menggunakan narkoba merupakan hal yang dilakukan atau dialami remaja sehingga menjadikan remaja tersebut menggunakan narkoba. Beberapa faktor yang menyebabkan kaum remaja rentan terhadap penyalahgunaan narkoba meliputi keluarga, sekolah dan teman sebaya. Penelitian Fitriani et al., (2017) terdapat beberapa faktor resiko yang menyebabkan remaja menyalahgunakan narkoba. Faktor resiko tersebut antara lain ketersediaan narkoba, kemudahan mendapat narkoba, jenis kelamin, pengetahuan, lingkungan keluarga, lingkungan teman (pergaulan) dan 
lingkungan sekolah. Pada penelitian ini, faktor yang teridentifikasi sebagai penyebab awal remaja menggunakan narkoba adalah factor dari teman, keluarga dan diri-sendiri.

Teman menjadi salah satu faktor penyebab remaja dalam penelitian ini untuk menggunakan narkoba. Pengaruh tersebut akhirnya membawa remaja untuk melakukan perilaku berisiko seperti terjerumus dalam penggunaan narkoba. Hal ini sesuai dengan hasil penelitian bahwa awal mula remaja menggunakan narkoba akibat ajakan dari teman. Penelitian Muhsinin et al., (2017) juga mengatakan bahwa teman sebaya mempunyai kecenderungan dalam penggunaan NAPZA pada remaja dengan $p$ value $=0.000$. Sejalan dengan penelitian Muttaqin \& Nurdin (2019) didapatkan bahwa pengguna narkoba dipengaruhi oleh lingkungan sekitar seperti lingkungan keluarga, lingkungan sekolah, lingkungan masyarakat, dan pergaulan sosial.

Sebagian besar remaja cenderung ditawari atau dibujuk oleh teman-teman untuk menggunakan narkoba. Melihat data survey tersebut, maka hasil penelitian ini sejalan dengan apa yang didapatkan sebelumnya. Seperti yang dinyatakan oleh P2 dan P4, yang menyatakan bahwa pergaluan dan teman mengajak mereka untuk mencicip atau menggunakan narkoba. Bebrapa partispan juga mengatakn awalnya diberikan gratis selanjutnya baru beli.

Pada penelitian ini remaja yang menjadi partisipan mengungkapkan bahwa karena orang tuanya bercerai dan juga sering dimarahi orang tua menjadikan remaja ingin mengkonsumsi narkoba. Banyak masalah yang timbul akibat kehilangan kasih sayang dalam keluarga, salah satunya adalah adanya konflik dalam keluarga baik itu antara ayah dan ibu atau antara orang tua dan anak. Hubungan orang tua dengan anak yang kurang baik juga menjadi faktor yang menyebabkan remaja menggunakan NAPZA. Konflik yang terjadi antara orang tua dengan anak akan membuat anak mencari kenyamanan diluar rumah. Sejalan dengan penelitian Muttaqin \& Nurdin (2019) didapatkan bahwa pengguna narkoba dipengaruhi oleh lingkungan sekitar seperti lingkungan keluarga. Keluarga merupakan benteng yang utama yang mempengaruhi penyimpangan remaja. Penelitian yang dilakukan Madyarartri et al., (2017) ada berbagai macam motif remaja yang menggunakan narkoba yakni karena kurangnya kasih sayang dan perhatian orang tua, digunakan untuk pelarian, coba-coba, untuk kesenangan saja, pengaruh lingkungan luar rumah.

Setelah teman dan keluarga, keinginan yang muncul dari remaja sendiri juga menjadi faktor penyebab remaja menggunakan narkoba. Hal ini jelas diungkapkan oleh partisipan seperti karena hasrat diri sendiri, ingin mencoba-coba atau karena frustasi dan kecewa. Partisipan yang usianya masih menginjak remaja menjadikan kepribadianya masih tergolong labil dan memiliki rasa ingin tahu yang tinggi. Menurut peneliti, ketiga faktor yang meliputi faktor dari teman, keluarga dan diri sendiri dapat membuat remaja terjerumus untuk melakukan perilaku yang kurang baik seperti mengkonsumsi narkoba. Adanya lingkungan teman yang sering menggunakan narkoba atau dari keluarga yang kurang harmonis menjadikan remaja ikut kedalam perilaku tersebut.

Hasil penelitian ini menunjukan adanya stimulus yang diterima oleh remaja baik itu secara internal maupun ekskternal. Stimulus internal berupa dari dalam diri sendiri atau secara kepribadian, sedangkan setimulus eksternal berupa lingkungan teman dan keluarga. Seluruh stimulus tersbeut merupakan stimulus yang mengajak atau memaksa remaja untuk menggunakan narkoba. Menurut peneliti, respon adaptif yang dimiliki oleh remaja belum terlihat begitu jelas pada penelitian ini. Namun, dengan adanya remaja yang terpengaruh oleh stimulus tersebut secara tidak langsung kemampuan adaptasi remaja dipengaruhi oleh lingkungan teman dan keluarga serta diri sendiri. 


\section{Tema 3 : Frekuensi Pemakaian Narkoba}

Jumlah pemakaian yang diungkapkan oleh partisipan sangat beragam. P1 dan p3 menyebutkan bahwa menggunakan narkoba hanya dua hari sekali. P1 menyebutkan penggunaan tersebut tergantung dengan ada atau tidaknya narkoba yang dimiliki. P2 menyebutkan menggunakan narkoba P2 menyebutkan jumlah pemakaian narkoba hanya seminggu sekali. Tidak jauh berbeda dengan P2, P6 juga mengatakan menggunakan narkoba hanya seminggu sehari. Sedangkan P4 dan P5 menyebutkan jumlah memakai narkoba adalah seminggu tiga kali.

Menurut peneliti, penggunaan narkoba memiliki ketergantungan yang tinggi. Remaja akan menggunakan narkoba terus menerus walaupun frekuensinya tidak sama setiap waktu. Penggunaan tersebut didominasi oleh laki-laki yang memiliki presentase $25 \%$ dibandingkan dengan perempuan. Sejalan dengan penelitian Fitriani et al., (2017) menunjukkan bahwa sebanyak $56 \%$ responden berisiko besar untuk menyalahgunakan narkoba. Dalam karakteristiknn responden, diketahui bahwa sebanyak 52,7\% responden berjenis kelamin lakilaki.

\section{Tema 4 : Jenis Narkoba yang Digunakan oleh Remaja}

Jenis narkoba merupakan salah satu hasil yang teridentifikasi dalam penelitian ini. Menurut survei yang dilakukan oleh pusat penelitian data dan informasi badan narkotika nasional, jenis narkoba yang pernah dipakai paling banyak adalah ganja $(3,34 \%)$. Ganja paling banyak dikonsumsi di Provinsi Sumatera Utara, Jambi, dan Maluku. Sesuai denan hasil penelitian hampir semua partispan pernah mengguakan ganja (Badan Narkotika Nasional RI, 2017).

Selain ganja, hasil penelitian ini juga menyebutkan narkoba jenis shabu-shabu yang pernah digunakan oleh partisipan 2,4,5 dan 6. Pada penelitian ini sebagian besar partisipan pernah menggunakan shabu-shabu. Hasil penelitian lainnya membuktikan bahwa beberaopa partisipan penelitian pernah menggunakan narkoba jenis Aibon. Hal ini diungkapkan oleh partisipan 2,3 dan 6. Zat adiktif lain memiliki presentase penggunaan yang termasuk kecil yaitu sebesar 5-10 \% menurut survei yang dilakukan oleh pusat penelitian data dan informasi badan narkotika nasional di 20 provinsi (Badan Narkotika Nasional, 2016). Menurut peneliti, penggunaan lem aibon sebagai tindakan narkoba dilakukan oleh sebagian remaja yang memiliki ekonomi menengah kebawah. Penggunaan Aibon disukai karena mudah ditemukan dengan harga yang terjangkau. Hal ini didukung juga oleh partisipan yang sebagian besar adalah remaja yang berasa dari keluarga ekonomi kebawah.

\section{Tema 5 : Cara Mendapatkan Narkoba}

Hasil penelitian ini menunjukan adanya sebuah cara yang dilakukan oleh remaja untuk mendapatkan narkoba sepertimembeli dari teman-teman. Pada penelitian ini, transaksi menjadi salah satu cara yang dilakukan oleh remaja untuk mendapatkan narkoba. Transaksi merupakan suatu kegiatan atau aktivitas jual beli antara dua belah pihak. Seluruh transaksi yang dilakukan oleh partisipan dalam penelitian ini berasal dari teman dan lingkungan sekitar. Teman menjadi sumber remaja dalam memperoleh narkoba. Hal ini juga didukung oleh survei pusat penelitian data dan informasi badan narkotika nasional di 20 provinsi, yang menyebutkan sumber pertama untuk mendapatkan narkoba adalah teman dengan presentase sebesar 95\%, sedangkan sisanya diperoleh dari apotik dan bandar narkoba (Badan Narkotika Nasional, 2016). 
Menurut peneliti, aktivitas transaksi baik dari teman dan lingkungan dapat terjadi ketika remaja ditawari oleh teman ataupun lingkungan yang terlalu banyak penjual narkoba. Sejalan dengan penelitian Sari (2018) menyebutkan bahwa upaya remaja dalam mendapatkan narkoba ditawari dan beli dari teman baik teman sekolah maupun teman diluar sekolah. Sesuai dengan hasil penelitian ini, partisipan mendapatkan narkoba dari teman yang ada di dilingkungan tempat tinggal dan di luar lingkungan tempat tinggal mereka. Partisipan mengatakan untuk mendapatkan narkoba mereka bisa mendapatkan dengan mudah dari teman mereka tanpa harus bersusah payah mencari ke bandar atau mencari pembelinya.

Penelitian yang dilakukan oleh Fitriani et al., (2017) menyebutkan bahwa kemudahan mendapatkan narkoba, ketersediaan narkoba, lingkungan baik itu dari lingkungan keluarga, lingkungan teman dan lingkungan sekolah merupakan factor resiko yang berhubungan dengan penyalahgunaan narkoba. Menurut peneliti, narkoba yang mudah dijangkau di lingkungan sekitar remaja yang menjadi partisipan pada penelitian ini, akan memberikan kesempatan remaja untuk melakukan transaksi. Hal ini dibuktikan oleh salah satu partisipan yang menyatakan bahwa di lingkungannya banyak menjual narkoba tersebut dan juga ada yang langsung ditawari oleh teman-temannya sehingga remaja tersebut dapat membeli dengan mudah.

Terdapat berbagai macam cara untuk memperoleh uang seperti dengan bekerja, berinvestasi dan lain sebaginya. Menurut survei yang dilakukan oleh pusat penelitian data dan informasi badan narkotika nasional untuk mendapatkan uang agar bisa pakai narkoba sebagian besar berasal dari uang saku yang diberikan orangtua (35\%), diikuti oleh pemberian teman secara gratis (24\%) (Badan Narkotika Nasional, 2016). Hasil Penelitian ini didapatkan remaja membutuhkan uang untuk melakukan proses jual beli narkoba. Hampir semua partisipan menggunakan uang saku sendiri untuk membeli narkoba, selain menggunakan uang saku mereka mencuri uang orang tua dan memaksa keluarga hingga menggadaikan barang yang dimiliki. Penelitian Sari (2018) mengatakan bahwa $39 \%$ remaja mendapatkan narkoba dengan cara menggunakan uang saku sendiri. Hasil penelitian tersebut sejalan dengan hasil penelitian, dalam mendapatkan narkoba remaja menggunakan uang jajan yang didapatkan dari orang tua untuk membeli narkoba bukan untuk membeli makanan ataupun minuman.

\section{Tema 6 : Upaya Remaja untuk Berhenti Menggunakan Narkoba}

Upaya yang dilakukan remaja untuk bisa berhenti mengunakan narkoba tergambar dari dua kategori seperti usaha sendiri dan usaha dari keluarga. Remaja mencoba mencari usaha untuk berhenti menggunakan narkoba diantaranya dengan usaha diri sendiri. Selain itu partispan empat mengatakan cara yang digunakan dengan beribadah, mendekatkan diri pada Allah. Sehingga menjadi tenang. Partisipan enam juga mengatakan mempunyai usaha dengan cara menjauhi lingkungan teman-teman yang menggunaan obat.

Usaha yang kedua adalah usaha keluarga dimana orang tuanya cepat-cepat membawa partisipan ke tempat rehabilitasi narkoba setelah mengetahui anaknya mengunakan narkoba ini. Selain itu ada juga usaha dari nenek yang akan membuatkan warung dan menikahkan cucunya jika sudah berhenti seperti.

Sejalan dengan penelitian Hawi (2018) untuk mengobati narkoba dengan rehabilitasi, seperti model psikoterapi yang berbasis psikologi dan model terapi moral yang berbasis spiritual yang digunakan efektif untuk mengobati pecandu narkoba dengan tahapan diawali dengan proses penyembuhan fisik, psikis dilanjutkan dengan spritual. Sesuai dengan hasil penelitian ini dimana keluarga partisipan sama-sama berusaha untuk menyembuhkan anaknya 
dengan cara membawa anaknya ke panti rehabilitasi dengan harapan mendapatkan kesembuhan dan lepas dari ketegantungan narkoba.

Selain itu dari partisipan sendiri yang dilakukan dengan cara menghindari penyebab remaja bisa menggunakan narkoba, seperti menghindari jaringan sosial, dalam penelitian partisipan mencoba untuk menjauhi lingkungan teman-teman yang menggunakan narkoba. Selain itu ada faktor internal tentang pengkuan diri untuk melakukan perubahan beberapa partisipan juga mencoba untuk benar-benar lepas dari narkoba salah satunya berubah dengan cara mendekatkan diri dengan cara beribadah.

Didukung hasil penelitian Crush et al., (2020) faktor dukungan sosial yang dirasakan terutama dari teman memiliki efek terhadap pengalaman psikotik remaja seluruh sampel dan dalam kelompok beresiko tinggi. Dalam analisis yang digunakan menunjukan adanya hubungan antara dukungan sosial dengan berkurangnya pengalaman psikotik remaja pada usia 18 tahun. Remaja yang memiliki dukungan sosial yang tinggi, maka kemungkinan akan berkurang pengalaman psikotik remaja tersebut ( $\mathrm{OR}=0.91,95 \%$ CI $0.89-0.93, \mathrm{p}<0.001$ ).

\section{Tema 7 : Perasaan Remaja Setelah Menggunakan Narkoba}

Perasaan yang dirasakan partisipan dalam menggunakan narkoba adalah perasaan menyesal, ini di ungkapkan oleh partisipan 1,2,3,4,5, dan 6. Hasil tema penelitian ini didapatkan dari kategori respon emosional remaja dalam menggunakan narkoba. Semua partisipan memberikan peryataan menyesal saat sudah mengunakan narkoba. Partisipan 1 mengatakan menyesal menggunakan itu karena hanya merusak badan dan tubuh. Dengan narkoba badanya menjadi kurus dan sering sakit. Partisipan 2 mengatakan menyesal menggunakan narkoba,karena narkoba hidupnya jadi malas setiap hari hanya begitu saja. Selain itu sering sakit dan dirawat di rumah sakit.

Partisipan 3 mengatakan menyesal menggunakan narkoba karena melanggar hukum dan benar-benar dilarang. Selain menyesal menggunakan narkoba karena setelah menggunakan itu seperti tidak bisa bernafas setelah menghisap obat tersebut. Partispan 4 mengatakan dengan menggunakan obat tersebut keluarga berantakan, bapaknya meninggal karena sakit lambung, dikarena selalu memikirkan anaknya yang menggunakn narkoba. Partispan 5 mengatakan menyesal menggunakan narkoba karena dilarang. Partsipan 6 mengatakan sangat menyesal menggunakan narkoba, karena menggunaka narkoba citacitanya tidak tercapai dan masa depanya rusak.

\section{Tema 8 : Harapan Remaja yang Menggunakan Narkoba}

Hasil penelitian tentang tema harapan didapatkan dari kategori dari keiginan remaja. keiginan remaja dalam menggunakan narkoba didapatkan dari pernyataan partispan 1,2,3,4,5, dan 6. Sesuai dengan hasil penelitian ini semua partisipan mengungkapan harapanya selama menggunakan narkoba seperti pada partispan 1 dan 4 mengatakan ingin sembuh dan punya istri, partisipan 2 mengatakan ingin bekerja,partisipan 3 mengatakan berharap dapat dukungan dari orang tua sehingga bisa sembuh dari kecanduan narkoba, partisipan 5 mengatakan ingin sembuh, mengejar cita-cita dan membahagiakan orang tua. Sedangkan untuk partispan 6 mengatakan ingin sembuh dan bebas dari narkoba. Berdasarkan dari hasil penelitian yang didapatkan semua remaja yang menggunakan narkoba mempunyia harapan yang besar dalam hidupnya. Semua ingin sembuh dari ketergantungan narkoba, ingin hidup kembali normal seperti biasa dan bisa mengejar mimpi dan cita-cita yang belum tercapai. 


\section{Tema 9 : Dampak Remaja yang Menggunakan Narkoba}

Hasil penelitian tentang tema dampak dari narkoba didapatkan dari tiga kategori yaitu pengaruh fisik, emosional, dan pengaruh sosial. Sebenarnya narkoba jika digunakan sekali dan dengan dosis yang kecil tidak akan menimbulkan dampak. Tetapi dengan perkembangan dan usia remaja yang mau coba-coba dengan hal baru maka narkoba disalah gunakan untuk kesenagan sehingga menimbulkan beberapa dampak seperti mudah marah, depresi, gangguan tidur, kekerasan, cemas, halusinasi, gelisah, nafsu makan bertambah, berfantasi. Sesuai dengan hasil penelitian ini didapatkan pengaruh yang muncul dari fisik partispan mengatakan bahwa ada rasa tiak enak dibadan, kejang, mata buram dan kurang tidur. Sedang untuk pengaruh emosinal didapatkan sering marah-marah, hancurin barang-barang dan menyendiri. Sedangkan pengaruh dari sosial mengatakan berhenti sekolah dan menyebabkan bapak meninggal. Semua partispan mengatakan mempunyai dampak yang buruk setelah menggunakan narkoba.

\section{Tema 10: Efek Remaja Jika Tidak Menggunakan Narkoba}

Dampak atau efek yang ditimbulkan oleh remaja jika tidak menggunakan narkoba pada penelitian ini digambarkan dari pernyataan keenam partisipan yang menyatakan gejalagejala yang dirasakannya jika tidak menggunakan narkoba. Dampak yang ditimbulkan oleh remaja jika tidak menggunakan narkoba dari penelitian ini didapatkan dua kategori yakni dampak yang dirasakan secara fisik dan emosional. Dampak fisik yang ditimbulkan remaja saat tidak menggunakan narkoba didukung dari pernyataan kelima partisipan yang menyatakan bahwa dirinya jika tidak menggunakan narkoba akan merasa lesu, pegal-pegal, lemas, dan menggiggil. Dua partisipan mengatakan bahwa dirinya merasa lesu jika tidak memakai narkoba sehingga untuk bekerja jadi tidak semangat (penyungkan). Satu partisipan mengatakan dampak fisik yang dirasakan jika tidak memakai narkoba yakni badan akan terasa pegal-pegal dan ngilu. Satu orang partisipan lainnya mengatakan jika tidak memakai narkoba badan akan terasa lemas karena efek obatnya yang tidak ada lagi dalam tubuh dan satu orang partisipan mengatakan bahwa jika tidak memakai narkoba tubuh akan terasa menggigil.

Dampak lain yang dirasakan oleh partisipan jika tidak menggunakan narkoba yakni dampak emosional. Dampak emosional yang dirasakan remaja dalam penelitian ini didukung oleh pernyataan kedua partisipan yang menyatakan bahwa yang dirasakan jika tidak menggunakan narkoba yakni partisipan akan merasa gelisah dan pusing. Satu partisipan mengatakan bahwa dirinya merasa gelisah jika tidak menggunakan narkoba dan rasanya tidak enak sehingga hal tersebut membuat dirinya selalu ingin menggunakan narkoba. Satu orang partisipan mengatakan bahwa dirinya merasa pusing tujuh keliling jika tidak menggunakan narkoba.

Dampak yang ditimbulkan remaja saat tidak mengkonsumsi narkoba baik secara fisik ataupun emosional ini akan membuat remaja mengalami kesulitan untuk lepas dari kebiasannya menggunakan narkoba, hal inilah yang akan membuat remaja semakin lama mengkonsumsi obat-obatan narkotika. Sulitnya lepas dari efek narkotika inilah yang akhirnya menjadikan remaja untuk terus mendapatkan narkoba dengan berbagai macam cara

\section{Tema 11: Persepsi Remaja Mengenai Narkoba}

Dalam penelitian ini persepsi remaja mengenai narkoba juga dipengaruhi oleh faktor pengalamannya yang pernah menggunakan narkoba. Persepsi remaja mengenai narkoba dalam penelitian juga didapatkan oleh remaja dari pengalamannya setelah menggunakan obat-obatan terlarang tersebut. Persepsi remaja mengenai narkoba dalam penelitian ini 
dimunculkan dari tanggapan keempat partisipan remaja terhadap narkoba. Partisipan menyatakan bahwa narkoba itu buruk dan dapat membuat badan menjadi kurus jika terusterusan dikonsumsi. Partisipan juga menyatakan bahwa menggunakan narkoba itu tidak enak karena dapat membuat kepala menjadi pusing jika terus menerus dikonsumsi. Partisipan lainnya menyatakan jika narkoba itu hanya digunakan untuk membuat happy dan menghilangkan kesuntukkan pikiran, bersenang-senang sambil berkumpul bersama temantemannya.

Penelitian ini teridentifikasi dari tanggapan remaja mengenai narkoba terdiri dari dua kategori yakni tanggapan positif dan tanggapan negatif. Tanggapan negatif dalam penelitian ini didukung oleh dua pernyataan partisipan yang mengatakan bahwa narkoba itu tidak enak dan buruk karena dapat mengakibatkan tubuh menjadi lebih kurus dan pusing jika dikonsumsi terus menerus. Badan Narkotika Nasional juga mengemukakan bahwa narkoba merupakan suatu zat psikotropika yang dapat mengakibatkan penderita mengalami pusing-pusing hebat (BNN, 2019). Tanggapan lainnya yang didapatkan dari partisipan yakni tanggapan positif. Dalam penelitian ini tanggapan positif yang dimunculkan oleh partisipan berdasarkan pengalamannya menggunakan narkoba yakni partisipan beranggapan bahwa narkoba dapat menghilangkan kesuntukkan pikiran, bersenang-senang sambil berkumpul bersama temantemannya dan membuatnya happy. Remaja yang pada masa tumbuh kembangnya memiliki rasa ingin tahu yang besar sering kali mencoba hal baru yang tidak pernah dilakukannya, salah satu faktor pergaulan yag dilakukan oleh teman-temannya dapat memberikan kesempatan remaja untuk mengenal hingga mencoba narkoba.

\section{Tema 12: Respon Remaja saat Menggunakan Narkoba}

Respon remaja saat menggunakan narkoba dalam penelitian ini digambarkan dari pernyataan partisipan yang menyatakan efek yang dirasakan remaja saat menggunakan narkoba. Respon menggunakan narkoba dalam penelitian ini dimunculkan dari efek yang dirasakan remaja saat menggunakan narkoba. Efek yang akan ditimbulkan dan dirasakan ketika seseorang menggunakan obat-obatan narkoba yaitu dirinya akan merasa tenang, semangat sehingga meningkatkan kegairahan dan efek berhalusinasi. Efek yang dirasakan remaja saat menggunakan narkoba dalam penelitian ini didukung dari pertanyaan partisipan bahwa saat pertama kali memakai narkoba dirinya merasakan kepalanya berputar dan terasa pening.

Partisipan juga mengatakan bahwa saat menggunakan narkoba dirinya lebih semangat dalam melakukan kegiatan sehari-hari dikarenakan efek yang dirasakan dari pengaruh obatobatan narkoba. Partisipan mengatakan saat memakai narkoba efek yang dirasakannya seperti mimpi terasa senang di hati sehingga membuat dirinya merasa lebih enak saat menggunakan narkoba. Efek lainnya yang dirasakan partisipan saat menggunakan narkoba yakni partisipan sering berhalusinasi. Partisipan juga mengatakan selain itu, efek yang dirasakan saat menggunakan narkoba yakni dirinya tidak merasa mengantuk sehingga dirinya tidak bisa tidur dan jantung terasa berdebar-debar.

Respon remaja yang mengatakan bahwa dirinya merasa lebih semangat saat memakai narkoba merupakan efek stimulan yang merangsang fungsi tubuh seseorang sehingga dapat meningkatkan kesadaran diri dan kegairahan saat memakainya, jenis stimulan yang dapat merangsang fungsi tubuh untuk lebih bergairah yakni kafein, kokain dan amphetamin yang merupakan kandungan di dalam obat-obatan narkotika seperti shabu-shabu dan ekstasi. Respon remaja lain yang mengatakan bahwa dirinya sering kali merasakan efek ngefly, berhalusinasi, dengan berkhayal merupakan suatu efek halusinogen akibat dari pemakaian obat-obatan narkoba. 


\section{SIMPULAN}

Hasil penelitian ini didapatkan 12 tema yaitu usia yang digunakan rata-rata berusia remaja awal, penyebab remaja menggunakan narkoba seperti dari lingkungan, teman dan juga faktor dari keluarga yang broken home dan frustasi. Dampak dalam menggunakan narkoba pada remaja didapatkan ada beberapa remaja yang mengatakan badanya kurus, kehilangan orang tua dan sampai berhenti sekolah. Harapanya remaja berharap bisa berhenti, menjalankan hidup dengan baik dan bisa membahagiakan orang tua meraka.

\section{SARAN}

Orang tua diharapkan selalu mendampingi anak dan memantau pergaulan remaja. Selain itu Memberikan kasih sayang, perlindungan dan perhatian pada anak pada masa-masa remaja. Untuk remaja lebih meningkatkan pengetahuan dan di harapkan lebih selektif dalam bergaul, memilih teman dan lebih terbuka pada keluarga.

\section{DAFTAR PUSTAKA}

Amanda, M. P., Humaedi, S., \& Santoso, M. B. (2017). Penyalahgunaan Narkoba di Kalangan Remaja (Adolescent Substance Abuse). Prosiding Penelitian dan Pengabdian Kepada Masyarakat, 4(2), 339-345. https://doi.org/10.24198/jppm.v4i2.14392

Badan Narkotika Nasional RI. (2017). Survei Nasional Penyalahgunaan Narkoba. BNN RI

BNN. (2019). Pengertian Narkoba dan Bahaya Narkoba Bagi kesehatan. Humas BNN. https://bnn.go.id/pengertian-narkoba-dan-bahaya-narkoba-bagi-kesehatan/

Crush, E., Arseneault, L., Danese, A., Jaffee, S. R., \& Fisher, H. L. (2020). Using Discordant Twin Method to Investigate an Environmentally Mediated Pathway Between Social Support and The Reduced Likelihood of Adolescent Psychotic Experiences. Psychological Medicine, 50(11), 1898-1905. https://doi.org/10.1017/S0033291719001983

Fitriani, O., Handayani, S., \& Asiah, N. (2017). Determinan Penyalahgunaan Narkoba pada Remaja di SMAN 24 Jakarta. ARKESMAS (Arsip Kesehatan Masyarakat), 2(1), 135-143. https://doi.org/10.22236/arkesmas.v2i1.516

Hawi, A. (2018). Remaja Pecandu Narkoba: Studi tentang Rehabilitasi Integratif di Panti Rehabilitasi Narkoba Pondok Pesantren Ar-Rahman Palembang. Tadrib: Jurnal Pendidikan Agama Islam, 4(1), 99-119. https://doi.org/10.19109/tadrib.v4i1.1958

Herman, H., Wibowo, A., \& Rahman, N. (2019). Perilaku Penyalahgunaan Narkoba di Kalangan Siswa Sekolah Menengah Atas Negeri 1 Banawa Kabupaten Donggala. MPPKI (Media Publikasi Promosi Kesehatan Indonesia): The Indonesian Journal of Health Promotion, 2(1), 21-26. https://doi.org/10.31934/mppki.v2i1.524

Madyarartri, Aisyah, S., \& Wahyudi, A. (2017). Motif Perilaku Menyimpang Remaja dengan Penyalahgunaan Narkoba di Kota Surabaya. Paradigma, 5(1), 1-58. https://jurnalmahasiswa.unesa.ac.id/index.php/paradigma/article/view/17695

Muhsinin, M., Huzaifah, Z., \& Khalilati, N. (2017). Pengaruh Teman Sebaya terhadap Kecenderungan Menggunakan Napza pada remaja di Banjarmasin. Caring Nursing Journal, 1(2), 64-68. https://journal.umbjm.ac.id/index.php/caringnursing/article/view/107

Muttaqin, D. M., \& Nurdin, A. (2019). Dramaturgi Pengguna Narkoba di Surabaya. Jurnal Ilmu Komunikasi, 9(1), 1-15. https://doi.org/10.15642/jik.2019.9.1.1-15 
Nur'artavia, M. R. (2017). Karakteristik Pelajar Penyalahgunaan NAPZA dan Jenis NAPZA yang Digunakan di Kota Surabaya. The Indonesian Journal of Public Health, 12(1), 27. https://doi.org/10.20473/ijph.v12i1.2017.27-38

Pusat Data dan Informasi. (2017). Infodatin Situasi Narkoba di Indonesia. Kementerian Kesehatan RI

Pusat Penelitian Data dan Informasi Badan Narkotika Nasional. (2016). Survei Prevalensi Penyalahgunaan Narkoba pada Kelompok Rumah Tangga di 20 Provinsi Tahun 2015. BNN

Sari, N. (2018). Tinjauan Yuridis terhadap Upaya Pelajar/Mahasiswa dalam Memperoleh Narkoba (Studi dalam Survei Penyalahgunaan Narkoba di Kelompok Pelajar dan Mahasiswa Tahun 2006). Jurnal Penelitian Hukum De Jure, 19(1), 121. https://doi.org/10.30641/dejure.2019.V19.121-136

Supratman, D. (2018). Prevalensi Usia Pemuda dan Ketahanan Nasional (Narkotika dan Ancaman Lost Generation). Jurnal Litbang Sukowati: Media Penelitian dan Pengembangan, 1(2), 118-127. https://doi.org/10.32630/sukowati.v1i2.29

Veronica, R. N., Langi, F. L. F. G., \& Joseph, W. B. S. (2018). Prevalensi dan Determinan Penggunaan Narkotika dan Obat-obatan Terlarang di Kalangan Remaja Indonesia. Jurnal Kesmas, 7(5), 1-10. https://ejournal.unsrat.ac.id/index.php/kesmas/article/view/22037 